\section{JURNAL ABDIMAS

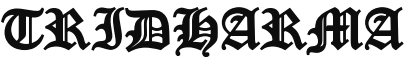 \\ 丹IA}

\title{
PELATIHAN KETERAMPILAN DAN KREATIVITAS GUNA MENINGKATKAN PENGHASILAN RUMAH TANGGA
}

\author{
(Studi Kasus Pada Kantor Kelurahan Ciputat, Ciputat, Tangerang Selatan)
}

\author{
Tutri Indraswari, Shella Puspita Sari, Kartika Sari Dewi, Ayu Puspa Lestiyadi \\ Dosen Magister Manajemen Universitas Pamulang \\ Emaildosen02446@unpam.ac.id,dosen02512@unpam.ac.id, \\ dosen02506@unpam.ac.id, dosen02505@unpam.ac.id
}

\begin{abstract}
ABSTRAK
Kegiatan Pegabdian Kepada Masyarakat ini bertujuan untuk memberikan pelatihan keterampilan dan kreativitasi guna meningkatkan penghasilan rumah tangga terhadap para staff ataupun peserta. Metode kegiatan yang digunakan adalah bekerjasama dengan Bapak Lurah Kelurahan Ciputat, yang beralamat di Ciputat, Tangerang Selatan dan memberikan pelatihan keterampilan dan peningkatan kreativitas untuk meningkatkan rasa kewirausahaan. Setelah dianalisis maka kami memberikan pelatihan dan pemaparan pembuatan Masker yang di hias dengan baik dan indah sehingga memiliki nilai jual. Hasil kegiatan menunjukkan bahwa sebelum pelaksanaan PKM, para staff kelurahan Ciputat belum mengetahui hal apa saja yang bisa dilakukan untuk meningkatkan penghasilan rumah tangga, namun setelah pelaksaan kegiatan PKM ini diketahui para peserta setidaknya sudah mempunyai sedikit bekal dan dapat memahami bagaimana membuat kerajinan yang murah dan mudah sebagai penambah penghasilan lain. Kegiatan PKM berperan positif dalam meningkatkan pengetahuan dan pengharapan untuk selalu meningkatkan jiwa berwirausaha.
\end{abstract}

Kata Kunci : PKM, Keterampilan, Kreativitas dan Wirausaha

\begin{abstract}
This Community Service activity aims to provide skills training and creativity to increase household income for staff or participants. The activity method used is to collaborate with the Head of the Ciputat Urban Village, whose address is in Ciputat, South Tangerang and to provide skills training and increase creativity to increase a sense of entrepreneurship. After being analyzed, we provide training and exposure to making masks that are decorated properly and beautifully so that they have a selling value. The results of the activity showed that prior to the implementation of PKM, the Ciputat urban village staff did not know what things could be done to increase household income, but after implementing this PKM activity it was found that the participants had at least a little provision and could understand how to make cheap and easy crafts. as an addition to other income. PKM activities play a positive role in increasing knowledge and expectations to always improve the entrepreneurial spirit.
\end{abstract}

Keywords: PKM, Skills, Creativity and Entrepreneurship

\section{PENDAHULUAN}

Globalisasi telah memunculkan tatanan kehidupan baru dan dalam sekejap merubah pola interaksi masyarakat dengan menyingkirkan batas-batas geografis, aktivitas manusia mengalami perubahan 


\section{JURNAL ABDIMAS

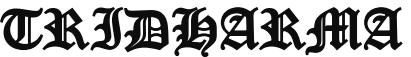

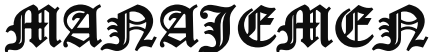

seiring dengan perkembangan zaman.Situasi dan kondisi sekarang ini tidak pernah diduga sama sekali. Hingga berbulan-bulan masyarakat mengalami keterbatasan gerak dan langkah keluar rumah.

Hampir seluruh kelas rumah tangga usaha terdampak pendapatannya akibat pandemi COVID-19, dibandingkan di rumah tangga pekerja kelas pendapatan yang paling terdampak adalah masyarakat dengan upah kurang dari Upah Minimum.Selain itu, semakin tinggi kelas pendapatan di rumah tangga pekerja maka semakin sedikit yang mengaku mengalami penurunan pendapatan.

Model dan pendekatan bisnis kewirausahaan yang dipengaruhi oleh pandemi akan berdampak pada bagaimana kewirausahaan dianggap sebagai pilihan pekerjaan di masa depan. Pandemi justru telah meningkatan kreativitas sejumlah orang dalam berbisnis, pembisnis dan perusahaan orang-orang dan perusahaan telah menyusun ide-ide baru untuk menanggapi kebutuhan yang ada atau yang pemenuhan kebutuhan yang tidak cukup ditangani oleh pemerintah dan lembaga yang berkuasa.

Gambaran tentang bagaimana wirausahawan dan sistem rumah tangga terpengaruh oleh pandemi jauh lebih kompleks dari yang dibayangkan, satu hal yang pasti adalah bagaimana bentuknya hari ini akan memiliki efek jangka panjang. Menyingkapi hal tersebut, baiknya setiap pelaku rumah tangga memiliki penghasilan lain yang dapat membantu memenuhi kebutuhan keluarganya dari segala aspek yang berdampak dimasa pandemi seperti sekarang ini.

Berdasarkan fenomena tersebut, kami para Dosen Universitas Pamulang dari Prodi Manajemen dan mahasiswa mengadakan Pengabdian Kepada Masyarakat (PKM) bersama dengan para staff kelurahan Ciputat, Ciputat, Tangerang Selatan untuk memberikan pengarahan terkait sosial media dengan tema "Pelatihan Keterampilan dan Kreativitas guna meningkatkan penghasilan rumah tangga pada staff di Kelurahan Ciputat, Ciputat, Tangerang Selatan".

\section{RUMUSAN MASALAH}

Berdasarkan latar belakang diatas dapat dirumusan permasalah dalam pelaksanaan pengabdian masyarakat bagi Staff Kelurahan Ciputat :

1. Bagaimana memberikan pemahaman tentang memperlakukan ekonomi rumah tangga di tengah masa pandemi saat ini kepada Staff Kelurahan Ciputat?

2. Bagaimana mengembangkan keterampilan dan kreativitas di tengah masa pandemi saat ini kepada Staff Kelurahan Ciputat

3. Bagaimana memberikan solusi - solusi alternatif sebagai penghasilan tambahan di tengah masa pandemi saat ini kepada Staff Kelurahan Ciputat?

4. Bagaimana memberikan pelatihan keterampilan dan kreativitas untuk menambah penghasilan lain kepada Staff Kelurahan Ciputat?

\section{TUJUAN PELAKSANAAN}

Tujuan Pelaksanaan Pengabdian Kepada Mayarakat di Kelurahan Ciputat adalah sebagai berikut :

1. Memberikan pemahaman tentang bagaimana memperlakukan ekonomi rumah tangga di tengah masa pandemi saat ini kepada Staff Kelurahan Ciputat.

2. Memberikan dan mengajarkan caracara mengembangkan keterampilan dan kreativitas di tengah masa pandemi saat ini kepada Staff Kelurahan Ciputat.

3. Memberikan pengarahan akan solusisolusi alternatif sebagai penghasilan tambahan di tengah masa pandemi saat ini kepada Staff Kelurahan Ciputat.

4. Memberikan pelatihan keterampilan dan kreativitas untuk menambah penghasilan lain kepada Staff Kelurahan Ciputat. 


\section{JURNAL ABDIMAS

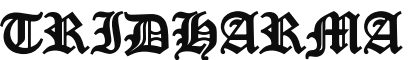

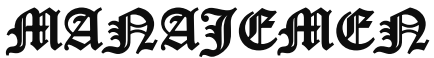

\section{TINJAUAN PUSTAKA}

\section{Keterampilan}

Menurut Kamus Besar Bahasa Indonesia, pelatihan berasal dari kata "latih" yang berarti olah, pelajaran untuk membiasakan atau memperoleh suatu kecakapan. Jadi, pelatihan berarti proses pembelajaran untuk membiasakan atau memperoleh suatukecakapan atau keahlian tertentu.

\section{a. Pengertian Keterampilan (skill)}

Skill adalah kemampuan untuk menggunakan akal, fikiran dan ide dan kreatifitas dalam mengerjakan, mengubah ataupun membuat sesuatu menjadi lebih bermakna sehingga menghasilkan sebuah nilai dari hasil pekerjaan tersebut.Ada juga pengertian lain yang mendefinisikan bahwa skill adalah suatu kemampuan untuk menerjemahkan pengetahuan ke dalam praktik sehingga tercapai hasil kerja yang diinginkan. Menurut Tommy Suprapto, (2009:135)

Berikut ini adalah berbagai pendapat tentangskill menurut para ahli, yaitu :

1) Menurut Gordon, skilladalah kemampuan untuk mengoperasikan pekerjaan secara mudah dan cermat.

2) Menurut Nadler, skillkegiatan yang memerlukan praktek atau dapat diartikan sebagai implikasi dari aktifitas.

3) Menurut Higgins, skilladalah kemampuan dalam tindakan dan memenuhi suatu tugas.

4) Menurut Iverson, skilladalah kemampuan untuk melakukan pekerjaan secara mudah dan tepat.Jika disimpulkan, skillberati kemampuan untuk mengoperasikan suatu pekerjaan secara mudah dan cermat. Menurut Susi dan soni (2008:158).

Keterampilan adalah hasil belajar pada ranah psikomotorik, yang terbentuk menyerupai hasil belajar kognitif. Keterampilan adalah kemampuan untuk mengerjakan atau melaksanakan sesuatu dengan baik. Maksud dari pendapat tersebut bahwa kemampuan adalah kecakapan dan potensi yang dimiliki oleh seseorang untuk menguasai suatu keahlian yang dimilikinya sejak lahir. Kemampuan tersebut merupakan suatu hasil latihan yang digunakan untuk melakukan sesuatu. Melalui pendapat Chaplin di atas dapat disimpulkan bahwa kemampuan seseorang itu dapat tumbuh melalui latihan-latihan yang dilakukan oleh orang itu sendiri. Menurut Yeti Mulyati (2007).

\section{Kreativitas}

\section{a. Pengertian Kreativitas}

Apa kalian kurang kreatif, kalian harus kreatif, kalian coba berpikir kreatif, berikan contah yang kreatif, lakukanlah yang kreatif, buatlah yang kreatif, carilah yang kreatif dan sebagainya. Kata-kata tersebut mungkin ialah kata yang sering keluar dalam ucapan kita.

Kata tersebut sering kali akan atau ingin atau dapat bermakna positif atau negatif. Dalam contoh kreatif dilingkungan kita sering terjadi dan terlihat hal demikian dimana kata kreatif, berkonotasi atau berarti negatif terhadap suatu barang atau seseorang.

Kreatif merupakan penunjang aktivitas dan apa yang kita lakukan saat ini dan kita gunakan. Berbagai manfaat kreativitas orang-orang, kini sangat membantu kita. Contoh kreatif ialah handphone yang kalian gunakan. Dulu handphone hanya digunakan untuk menelpon dan mengirim sms, sekarang handphone atau smartphone digunakan dapat membuka internet atau social media atau sedang melihat informasi ini.

Definisi kreatif terkadang digunakan oleh para pengguna bahasa, baik yang bertujuan positif maupun juga negatif. Secara singkat dan sederhana pengertian kreatif ialah suatu 


\section{JURNAL ABDIMAS

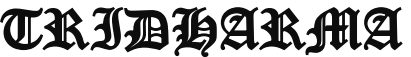

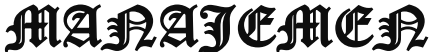

kemampuan yang dimiliki seseorang "atau sekelompok orang" yang memungkinkan mereka menemukan pendekatan-pendekatan atau terobosan baru dalam menghadapi situasi atau masalah tertentu yang biasanya tercermin dalam pemecahan masalah dengan cara yang baru dan juga unik yang berbeda dan lebih baik dari sebelumnya.

Kata "kreatif" merupakan kata yang berasal dari bahasa Inggris To: Create yang merupakan singkatan dari: Combine "menggabungkan", penggabungan suatu hal dengan hal lain, Reverse "membalik", membalik beberapa bagian atau proses, Eliminate "menghilangkan", menghilangkan beberapa bagian, Alternatif "kemungkinan", menggunakan cara dengan yang lain, Twist "memutar", memutarkan sesuatu dengan ikatan, Elaborate "memerinci", memerinci atau menambah sesuatu.

Menurut Clark Moustakis dalam Ridwan (Ridwan, 2006:252) mengemukakan bahwa kreativitas adalah pengalaman mengekspresikan dan mengaktualisasikan identitasindividu dalam bentuk terpadudalam hubungan diri sendiri dengan alam dan dengan orang lain. Menurut Utami Munandar (2009:18) menyatakan bahwa kreativitas adalah suatu kemampuan untuk mencerminkan kelancaran, keluwesan (fleksibilitas), orisinalitasdalam

berfikir, dan kemampuan mengelaborasi (mengembangkan, memperkaya, dan merinci) suatu gagasan.

Kreativitas membutuhkan proses yang menuntut kecakapan, keterampilan, dan motivasi yang kuat.Kreativitas yang merupakan hasil dari berpikir kreatif sangat penting bagi kehidupan manusia. Utami Munandar mengatakan alasan mengapa kreativitas pada diri siswa perlu dikembangkan.16 Pertama, dengan berkreasi maka orang dapat mewujudkan dirinya (self actualization), dan ini merupakan kebutuhan setiap manusia untuk mewujudkannya. Kedua, sekalipun setiap orang menganggap bahwa kreativitas itu perlu dikembangkan, namun perhatian terhadap pengembangan kreativitas belum memadai khususnya dalampendidikan formal. Ketiga, menyibukkan diri secara kreatif tidak hanya bermanfaat tapi juga memberikan kepuasan tersendiri. Keempat, kreativitaslah yang memungkinkan manusia untuk meningkatkan kualitas hidupnya. Untuk hal ini perlu disadari bagaimana para pendahulu yang kreatif telah menolong manusia dalam memecahkan berbahgai permasalahan yang menghimpit manusia Dari beberapa pendapat di atas, dapat disimpulkan bahwa kreativitas adalah suatu kemampuan untuk menciptakan sesuatu yang baru yang berbeda dari sebelumnya, baik berupa gagasan atau karya nyata dengan menggabunggabungkan unsur-unsur yang sudah ada sebelumnya. Hal baru disini adalah sesuatu yang belum diketahui oleh yang bersangkutan, meskipun hal itu merupakan hal yang tidak asing lagi bagi orang lain, dan bukan hanya dari yang tidak menjadi ada, tetapi juga kombinasi baru dari sesuatu yang sudah ada.

\section{Penghasilan}

\section{a. Pengertian Penghasilan}

Pendapatan bukanlah istilah yang asing bagi masyarakat Indonesia. Semua orang dari segala usia, status sosial, ekonomi dan budayapasti pernah mendengar atau bahkan mengucapkan kata pendapatan. Di Indonesia, ada cukup banyak terminologi yang dikaitkan dengan pendapatan. Seperti misalnya pendapatan keluarga, pendapatan masyarakat, pendapatan per kapita, 


\section{JURNAL ABDIMAS

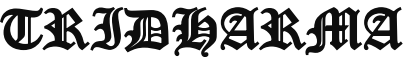

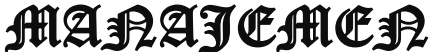

pendapatan daerah, hingga pendapatan negara.

Pendapatan berasal dari kata dasar "dapat". Menurut Kamus Besar Bahasa Indonesia, pengertian pendapatan adalah hasil kerja (usaha dan sebagainya). Pengertian pendapatan menurut Kamus Besar Bahasa Indonesia merupakan definisi pendapatan secara umum. Pada perkembangannya, pengertian pendapatan memiliki penafsiran yang berbeda-beda tergantung dari latar belakang disiplin ilmu yang digunakan untuk menyusun konsep pendapatan bagi pihak-pihak tertentu.

Setidaknya terdapat dua disiplin ilmu yang memiliki penafsiran tersendiri mengenai pengertian pendapatan. Disiplin ilmu yang pertama adalah Ilmu Ekonomi sedangkan yang kedua adalah disiplin Ilmu Akuntansi. Pengertian pendapatan menurut Ilmu Ekonomi adalah nilai maksimum yang dapat dikonsumsi seseorang dalam suatu periode dengan mengharapkan keadaan yang sama pada akhir periode seperti keadaan semula. Pengertian pendapatan menurut Ilmu Ekonomi menitikberatkan pada total kuantitatif pengeluaran terhadap konsumsi selama satu periode. Dengan kata lain, pengertian pendapatan menurut Ilmu Ekonomi adalah jumlah harta kekayaan awal periode ditambah keseluruhan hasil yang diperoleh selama satu periode, bukan hanya yang dikonsumsi.

Pengertian pendapatan menurut Ilmu Ekonomi menutup kemungkinan perubahan lebih dari total harta kekayaan badan usaha pada awal periode dan menekankan pada jumlah nilai statis pada akhir periode. Secara sederhana, pengertian pendapatan menurut Ilmu Ekonomi adalah jumlah harta kekayaan awal periode ditambah perubahan penilaian yang bukan diakibatkan perubahan modal dan hutang.

Sedikit berbeda dengan pengertian pendapatan menurut Ilmu Ekonomi, pengertian pendapatan menurut Ilmu Akuntansi memiliki cukup banyak konsep yang diperoleh dari berbagai literatur akuntansi dan teori akuntansi. Ilmu akuntansi melihat pendapatan sebagai sesuatu yang spesifik dalam pengertian yang lebih mendalam dan terarah. Pada dasarnya, pengertian pendapatan menurut Ilmu Akuntansi dapat ditelusuri dari dua sudut pandang, yaitu:

1) Konsep Pendapatan yang memusatkan pada arus masuk (inflow) aktiva sebagai hasil dari kegiatan operasi perusahaan. Pendekatan ini menganggap pendapatan sebagai inflow of net asset.

2) Konsep Pendapatan yang memusatkan perhatian kepada penciptaan barang dan jasa serta penyaluran konsumen atau produsen lainnya, jadi pendekatan ini menganggap pendapatan sebagai outflow of good and services.

Pendapatan adalah seluruh penerimaan berupa uang maupun berupa barang yang berasal dari pihak lain maupun hasil industri yang dinilai atas dasar sejumlah uang dari harta yang berlaku saat itu. Pendapatan merupakan sumber penghasilan seseorang untuk memenuhi kebutuhan sehari-hari dan sangat penting artinya bagi kelangsungan hidup dan penghidupan seseorang secara langsung mau pun tidak lagsung (Suroto, 2000:26).Pendapatan sangat berpengaruh bagi kelangsungan suatu usaha, semakin besar pendapatan yang diperoleh maka semakin besar kemampuan suatu usaha untuk 


\section{JURNAL ABDIMAS

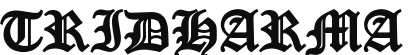

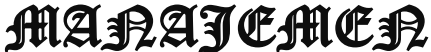

membiayai segala pengeluaran dan kegiatan -kegiatan yang akan dilakukan. Kondisi seseorang dapat diukur dengan menggunakan konsep pendapatan yang menujukkan jumlah seluruh uang yang diterima oleh seseorang atau rumah tangga selama jangka waktu tertentu (Samuelson dan Nordhaus, 2013) Ada definisi lain mengenai pendapatan yaitu pendapatan dikatakan sebagai jumlah penghasilan yang diperoleh dari hasil pekerjaan dan biasanya pendapatan seseorang dihitung setiap tahun atau setiap bulanMenurut John J. Wild (2003;311) secara garis besar pendapatan dapat ditinjau dari dua sisi, yaitu :

\section{a. Pendapatan Menurut Ilmu Ekonomi}

Menurut ilmu ekonomi, pendapatan merupakan nilai maksimum yang dapat dikonsumsi oleh seseorang dalam suatu periode dengan mengharapkan keadaan yang sama pada akhir periode seperti keadaan semula. Definisi pendapatan menurut ilmu ekonomi menutup kemungkinan perubahan lebih dari total harta kekayaan badan usaha pada awal periode dan menekankan pada jumlah nilai statis pada akhir periode. Dengan kata lain, pendapatan adalah jumlah kenaikan harta kekayaan karena perubahan penilaian yang bukan diakibatkan perubahan modal dan hutang.

b. Pendapatan Menurut Ilmu Akuntansi

Pandangan akuntansi memiliki keanekaragaman dalam memberikan pengertian pendapatan. Ilmu akuntansi melihat pendapatan sebagai sesuatu yang spesifik dalam pengertian yang lebih mendalam dan lebih terarah. Pada dasarnya konsep pendapatan menurut ilmu akuntansi dapat ditelusuri dari dua sudut pandang, yaitu :

Pandangan

menekankan

yang

pertumbuhan

peningkatan jumlah aktiva yang timbul sebagai hasil dari kegiatan operasional perusahaan pendekatan yang memusatkan perhatian kepada arus masuk atau inflow. Menurut SFAC (Statement of Financial Accounting Concepts) No.6, menekankan pengertian pendapatan pada arus masuk atau peningkatanpeningkatan lainnya atas aktiva suatu entitas atau penyelesaian kewajibankewajibannya atau kombinasi keduanya yang berasal dari pengiriman atau produksi barang, penyelenggara jasa, pelaksanaan aktivitasaktivitas lainnya yang merupakan kegiatan operasi utama entitas tersebut yang berlangsung terus-menerus. Pandangan yang menekankan kepada penciptaan barang dan jasa oleh perusahaan serta penyerahan barang dan jasa atau outflow.

\section{METODE PELAKSANAAN}

Metode kegiatan ini berupa sosialisasi Dan Pelatihan Penggunaan Aplikasi E-Court,berikut ini adalah tahapan pelatihan yang dilakukan:

1. Tahap Persiapan

Tahap persiapan yang dilakukan meliputi: 


\section{JURNAL ABDIMAS

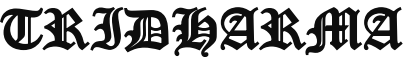

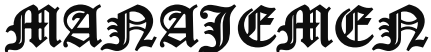

a. Survey awal, pada tahap ini dilakukan survei ke lokasi Kantor Kelurahan Ciputat yang beralamat di Jl. Ki Hajar Dewantara, No. 7 Kec. Ciputat, Kota Tangerang Selatan

b. Pemantapan dan penentuan lokasi dan sasaran. Setelah survey maka ditentukan lokasi pelaksanaan dan sasaran peserta kegiatan.

c. Penyusunan bahan/materi sosialisasi pelatihan pembuatan masker hias

2. Tahap Pelaksanaan Penelitian

Tahap ini akan diberikan penjelasan mengenai cara penggunaan pembuatan masker hias

3. Tahap Penyuluhan

Untuk melaksanakan kegiatan tersebut digunakan beberapa metode penyuluhan yaitu:

a. Metode Ceramah

Metode ceramah dipilih untuk memberikan penjelasan tentang pentingnya menggunakan masker di masa pandemic COVID-19

b. Metode Tanya Jawab

Metode Tanya jawab sangat penting bagi para peserta pelatihan. Metode ini memungkinkan para peserta menggali pengetahuan sebanyakbanyaknya tentang pembuatan masker hias

c. Metode Simulasi

Metode simulasi ini diberikan kepada para peserta penyuluhan dengan memberikan contoh cara pembuatan masker dengan menggunakan sebuah video

\section{HASIL DAN PEMBAHASAN}

Setelah dilaksanakan Pengarahan serta pengimplementasian media sosial, maka tingkat keberhasilan penyelenggaraan kegiatan Pengabdian Kepada Masyarakat ini dapat dilihat dari hasil evaluasi selama pelaksanaan kegiatan, yaitu:
1. Evaluasi proses yaitu untuk mengetahui pelaksanaan dari program yang dibuat serta keterlibatan peserta atau khalayak sasaran antara strategis selama mengikuti kegiatan. Evaluasi ini dilakukan dari awal sampai akhir kegiatan dengan melihat tanggapan peserta penjelasan dan contoh-contoh yang diberikan, melakukan sesi tanya jawab yang interkatif namun hanya ada beberapa staff atau peserta yang belum bisa menangkap materi dengan baik dikarenakan usia.

2. Evaluasi hasil yaitu untuk mengetahui seberapa jauh tingkat keberhasilan tujuan yang telah dirumuskan, dapat dilihat dari respon (tanggapan) peserta terhadap sosialisasi pelatihan yang telah dilakukan pada saat kegiatan berlangsung.

Pelatihan dilakukan selama dua hari pada tanggal 08 s/d 09 Oktober 2020 dihadiri perserta di Kantor kelurahan sebanyak 25 peserta. Semua peserta mengikuti kegiatan secara penuh dikarenakan semua peserta antusias mengikuti kegiatan pengarahan dan pengimplentasian. Dari respon (tanggapan peserta) yang diberikan meraka semua sangat berharap kegiatan Pengabdian Kepada Masyarakat seperti ini dalam dilakukan kembali pada periode-periode berikutnya. Adapun beberapa faktor pendorong terlaksananya kegiatan pelatihan ini adalah sebagai berikut:

1. Dari pihak peserta (para staff kelurahan) begitu antusias dalam mengikuti seluruh rangkaian kegiatan pengabdian pada masyarakat ini.

2. Pelaksanaan kegiatan ini dapat memberikan pengetahuan tambahan/menambah wawasan bagi peserta mengenai pengembangan keterampilan dan kreativitas.

3. Kesiapan dan semangat para peserta kegiatan ini begitu besar untuk mendapatkan pengetahuan yang disiapkan oleh panitia pelaksana.

4. Faktor pendorong lainnya adalah kesiapan anggota tim pelaksana yang 


\section{JURNAL ABDIMAS

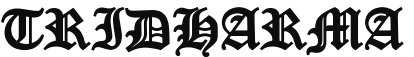

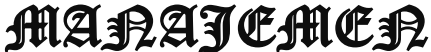

telah menyiapkan diri, terutama dalam pemberi materi pada kegiatan pengabdian ini sangatlah interaktif dan memberikan suasana yang bersahaja.

\section{KESIMPULAN DAN SARAN Kesimpulan}

Pelaksanaan kegiatan pengabdian kepada masyarakat oleh Lembaga Penelitian dan Pengabdian Masyarakat (LPPM) Universitas Pamulang yang dilakukan oleh dosen-dosen Universitas pada program studi manajemen telah berjalan dengan lancar dan mendapat sambutan hangat dari tempat pelaksanaan kegiatan ini yaitu Kantor Kelurahan Ciputat, Ciputat, Tangerang Selatan.

Harapan kami selaku dosen, dengan pengabdian ini dapat menambah pemahaman dan wawasan tentang bagaimana meningkatkan keterampilan dan kreativitas yang perlu dilakukan guna meningkatkan penghasilan tambahan lain bagi masing-masing rumah tangga

Materi yang kami berikan yaitu tentang gambaran secara umum dan pelatihan keterampilan dan kreativitas yang perlu dilakukan guna meningkatkan femahaman para peserta dan membangkitkan keinginan untuk berwirausaha dan dapat mengimplementasikan ilmu yang di dapat dalam pelatihan ini dalam kehidupan sehari-hari, sehingga dapat membantu dan meningkatkan taraf ekonomi rumah tangga yang sehat dan bermanfaat dalam kehidupan mereka pada masa yang akan datang.

\section{Saran}

Dalam laporan kegiatan ini mungkin banyak kekurangan yang ada, untuk itu kami berharap masukan dan kritikan dalam rangka perbaikan untuk kegiatan-kegiatan pengabdian masyarakat di masa yang akan datang. Semoga kegiatan pengabdian masyarakat ini dapat bermanfaat bagi masyarakat sekitar Universitas Pamulang.
Akhirnya, kami mengucapkan terima kasih kepada seluruh pihak yang telah mendukung kegiatan yang kami laksanakan dan kami mohon maaf apabila dalam laporan ini banyak ditemukan kekurangan.

\section{DAFTAR PUSTAKA.}

Achmad, Nur. 2015. Kewirausahaan: Suatu Alternatif Lain Menuju Kesuksesan.

Surakarta: BPK FEB UMS.

Achmad, Nur., Saputro, Edy Purwo dan Handayani, Sih. 2016. Kewirausahaan di

Era Digital. Jakarta: Direktorat Penelitian Pengabdian Masyarakat Dirjen

Dikti.

Achmad, Nur dan Saputro, Edy Purwo. 2015. Isu Riset Kewirausahaan. Jakarta

Alma, Buchari, 2009. Kewirausahaan. Bandung: Alfa Beta.

Azwar, Saifuddin, Metode Penelitian, Yogyakarta: Pustaka Pelajar, 2010.

Kasmir. 2010. Kewirausahaan. Jakarta: PT Raja Grafindo Persada

Mayasari, R. (2014). Pengaruh Keterampilan Sosial dan Efikasi Diri Sosial Terhadap Kesejahteraan Psikologis. AlMunzir, 7(1).

Mulyasa, E, Menjadi Guru Profesional Menciptakan Pembelajaran Kreatif dan Menyenangkan, Bandung: PT Remaja Rosdakarya, 2008.

Pasaribu, V. L. D., Susanti, F., \& Hartuti, E. T. K. (2019). Memotivasi Siswa dan Siswi SMK Letris Indonesia di Dalam Menentukan Pilihan Untuk Melanjutkan Pendidikan Atau Bekerja Setelah Lulus Sekolah. Jurnal Pengabdian Dharma Laksana, 1(2), 161-172.

Pasaribu, V. L. D., Agrasadya, A., Shabrina, N., \& Krisnaldy, K. (2020). 


\section{JURNAL ABDIMAS

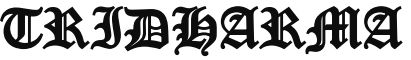 AIA}

P-ISSN 2715-7105, E-ISSN 2716-070X

Jurnal ABDIMAS Vol. 2, No. 1, Januari 2021,Hal (44-53)

@Prodi Manajemen Fakultas Ekonomi Universitas Pamulang

Email: abdimasjurnal.unpam@gmail.com Telp: (021) 741-2566
MENJADI ENTERPRENEUR MUDA YANG MEMILIKI JIWA LEADERSHIP UNTUK MENGHADAPI MASA DEPAN. Abdi Laksana, 1(1).

Pasaribu, V. L. D., Elburdah, R. P., Sudarso, E., \& Fauziah, G. (2020). PENGGUNAAN MANAJEMEN WAKTU TERHADAP PENINGKATAN PRESTASI BELAJAR DI SMP ARAISIYAH. Jurnal ABDIMAS Tri Dharma Manajemen, 1(1).

Pasaribu, V. L. D., Sulaiman, S., Sutiman, S., Thaharudin, T., \& Purnomo, B. Y. (2020). PENGENALAN LETAK POSYANDU TERDEKAT DIKELURAHAN PISANGAN DENGAN MANAJEMEN

REVOLUSI $\quad 4.0 \quad$ UNTUK MENINGKATKAN PENGETAHUAN MASYARAKAT LETAK DAN FUNGSI POSYANDU TERDEKAT PADA KELURAHAN PISANGAN. DEDIKASI PKM, 1(1), 105-110.

Pasaribu, V. L. D., Oktrima, B., Prabowo, B., Arianto, N., \& Haryoko, U. B. (2020). PROGAM PENDAMPINGAN DAN PENYELENGGARAAN PENDIDIKAN ANAK PADA USIA DINI TERHADAP PRESTASI BELAJAR DILINGKUNGAN RT 020 RW 009. KEL GIRI PENI. KEC WATES. YOGYAKARTA. JURNAL LOKABMAS KREATIF, 1(1), 71-75

Saputro, Edy Purwo., Achmad, Nur dan Handayani, Sih. 2016. Identifikasi Faktor yang Mempengaruhi Sukses Wirausaha. Benefit, Jurnal Manajemen dan Bisnis. Volume 1, Nomor 1.

Suryana. (2011). Kewirausahaan. Jakarta: Penerbit Salemba Empat.

Suryana. (2013). Kewiraushaan Kiat dan Proses Menuju Sukses. Jakarta: Salemba Empat. Direktorat Penelitian Pengabdian Masyarakat Dirjen Dikti.
Yuyun Wirasasmita. 2003. Komunikasi Bisnis. Jakarta : PT Gramedia Pustaka Utama.
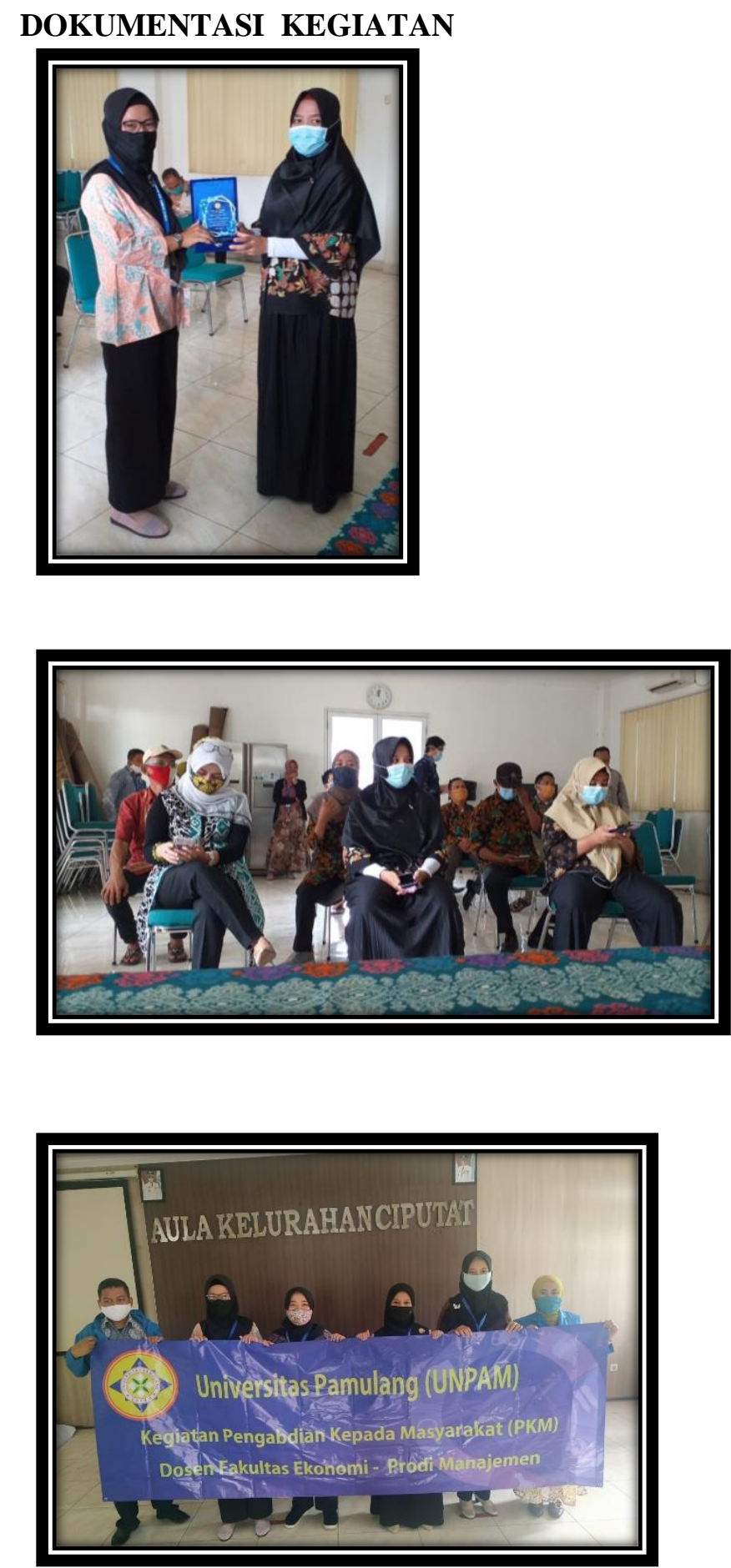
JURNAL ABDIMAS

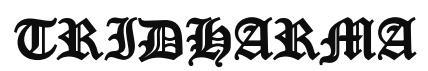

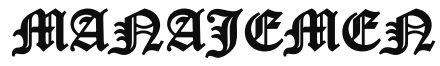
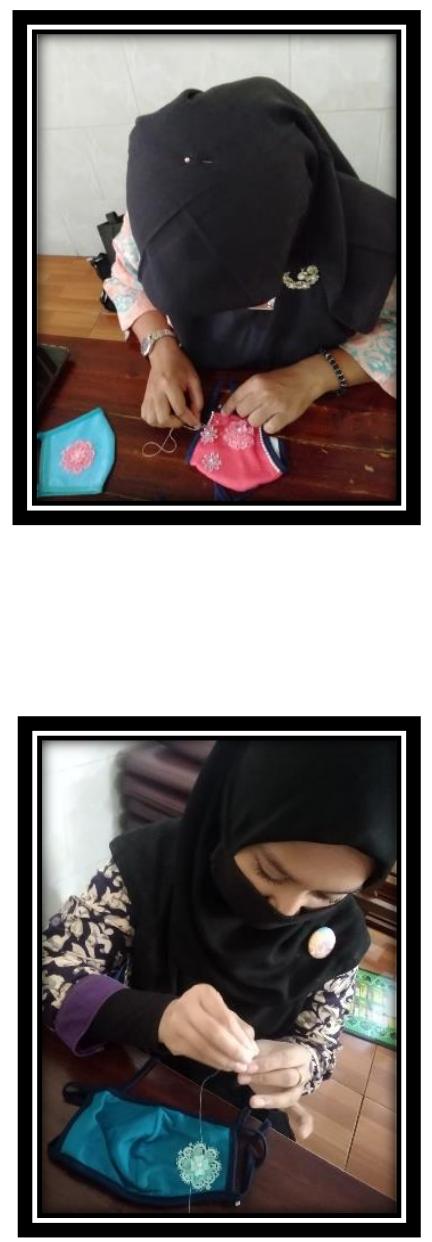

P-ISSN 2715-7105, E-ISSN 2716-070X

Jurnal ABDIMAS Vol. 2, No. 1, Januari 2021,Hal (44-53)

@ Prodi Manajemen Fakultas Ekonomi Universitas Pamulang

Email: abdimasjurnal.unpam@gmail.com Telp: (021) 741-2566
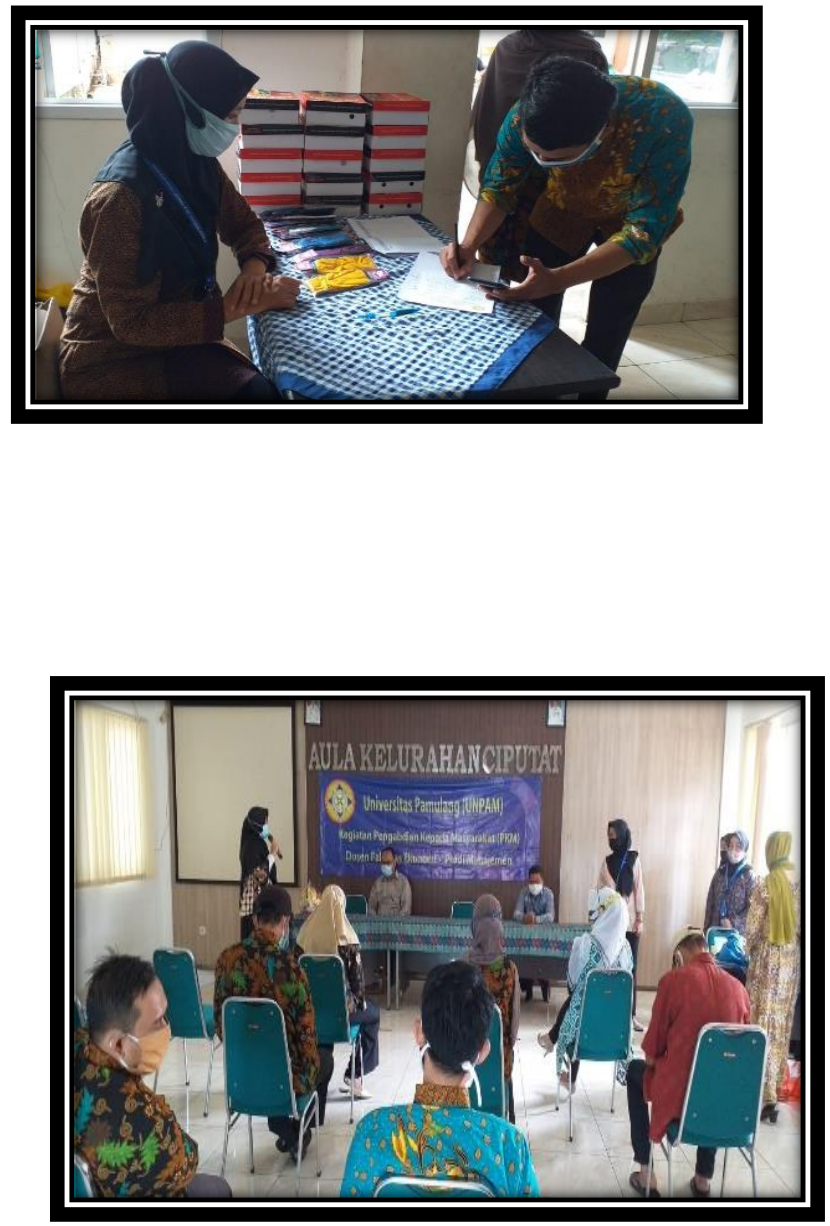